\title{
Genetic Diversity Analysis in wild species of Pongamia pinnata (L.) using RAPD and SRAP markers
}

\author{
Pravas Ranjan Kole ${ }^{1}, \mathrm{~K}$ V Bhat ${ }^{2}$, Rekha Chaudhury ${ }^{3}$, S. K. Malik ${ }^{3}$ and G. Rajeshwar Rao ${ }^{4}$
}

1 School of Applied Science, RMIT University, Building 223, Level 1, Plenty Road, Bundoora, Victoria. 3983. prkole1979@gmail.com

2 Division of Genomic Resources, National Bureau of Plant Genetic Resources, Pusa Campus,New Delhi110012.

Kvbhat2001@yahoo.com

3 Tissue Culture \& Cryopreservation Unit, National Bureau of Plant Genetic Resources, Pusa Campus,New Delhi-110012.

rekha@nbpgr.ernet.in, skm1909@gmail.com

4 CRIDA (ICAR), Santoshnagar, Hyderabad - 500059

Correspondent Address:

1 School of Applied Science, RMIT University, Building 223, Level 1, Plenty Road, Bundoora, Victoria. 3983.

\section{ABSTRACT}

prkole1979@gmail.com

\begin{abstract}
Bio -diversity refers to the variations within the living world while genetic diversity is the sum of genetic characteristics within any species or genus. Genetic diversity serves as a way for populations to adapt to changing environments. With more variation, it is more likely that some individuals in a population will possess variations of alleles that are suited for the environment. Those individuals are more likely to survive to produce offspring bearing that allele. The population will continue for more generations because of the success of these individuals. The extensive literature survey revealed that Pongamia Pinnata L. is an important medicinal plant with diverse pharmacological spectrum. The plant shows the presence of many chemical constituents which are responsible for varied pharmacological and medicinal properties. Furthermore, it also represents a milestone in the field of biofuel industry as one of the most important bio fuel crop. The present investigation was carried out to assess the genetic diversity of 37 wild species of $P$. pinnata collected from different states from India based on random amplified polymorphic DNA (RAPD) and Sequenced Related Amplified Polymorphism (SRAP) primers. After screening a total of 18 RAPD and 23 SRAP primers were used which gave reproducible amplification banding patterns. In RAPD out of 157 alleles were generated of which 150 were polymorphic across the studied accessions (96.8\% polymorphism). For SRAP the total number of amplified products was 145 of which 122 were polymorphic $(84.1 \%$ polymorphism). The mean polymorphic information content (PIC) for both the markers was 0.77 and 0.68 . Variation in combined Jaccard's coefficient of similarity indicates the high level of genetic variation among the genotypes studied. The overall grouping pattern of clustering corresponds well with the principal component analysis (PCA), confirming patterns of genetic diversity observed among the accessions.
\end{abstract}

\section{Indexing terms/Keywords}

Genetic Diversity; Molecular Marker; Pongamia; RAPD; SRAP.

\section{Academic Disipline And Sub-Disciplines}

Biotechnology

\section{Subject Classification}

Biology

\section{Type (Method/Approach)}

\section{Experimental}

\section{Council for Innovative Research}

Peer Review Research Publishing System

Journal: JOURNAL OF ADVANCES IN BIOTECHNOLOGY

Vol .4, No. 3

www.cirjbt.com , jbteditor@gmail.com 


\section{INTRODUCTION}

Pongamia pinnata (L.) Pierre is a medium sized glabrous tree popularly known as Karanja, Indian Beech and Pongam. It is widely distributed throughout tropical Asia and the Seychelles Islands, South Eastern Asia, Australia and India. It is a medicinal plant native to Western Ghats and chiefly found in tidal forests of India. The tree is known for its multipurpose benefits and as a potential source of biodiesel. The seeds are reported to contain on an average about 28-34\% oil with high percentage of polyunsaturated fatty acids. Besides, it is well known for its application as animal fodder, green manure, timber and fish poison. It has also been recognized to possess applications in agriculture and environmental management with insecticidal and nematicidal activity. Historically, Pongamia has been used as folk medicinal plant, particularly in Ayurvedha and Siddha systems of Indian medicine. All parts of the plant have been used as a crude drug for the treatment of tumors, piles, skin diseases, itches, abscess, painful rheumatic joints wounds, ulcers, diarrhea etc. More recently, the effectiveness of $P$. pinnata has been reported as a source of biomedicines, specifically as antimicrobial and therapeutic agents.

Various approaches are available for DNA fingerprinting such as amplified fragment length polymorphism (AFLP) (Zabeau and Vos 1993), restriction fragment length polymorphism (RFLP) (Botstein et al. 1980), randomly amplified polymorphic DNAs (RAPD) (Williams et al. 1990) and simple sequence repeats (SSRs) (Tautz 1989). Among these, RAPD is an inexpensive and rapid method not requiring any information regarding the genome of the plant, and has been widely used to ascertain the genetic diversity in several plants (Belaj et al. 2001; Deshwall et al. 2005). RAPD analysis requires only a small amount of genomic DNA and can produce high levels of polymorphism and may facilitate more effective diversity analysis in plants (Williams et al. 1990). RAPD analysis provides information that can help define the distinctiveness of species and phylogenetic relationships at molecular level. Use of such techniques for germplasm characterization may facilitate the conservation and utilization of plant genetic resources, permitting the identification of unique genotypes or sources of genetically diverse genotypes. RAPD analysis has been used for genetic diversity assessment and for identifying germplasm in a number of plant species (Kapteyn and Simon 2002; Welsh and McClelland 1990).

Sequence related amplified polymorphism (SRAP) is a PCR-based marker system as described by Li and Quiros (2001). It is a simple and efficient marker system that can be adapted for a variety of purposes in different crops, including map construction, gene tagging, genomic and cDNA fingerprinting, and map-based cloning (Wu et al. 2010). Currently, SRAP markers have been shown to be effective for DNA fingerprinting, genetic diversity analyses, and germplasm evaluation. About the genetic diversity, SRAPs provide a reliable tool for estimation of the degree of genetic relatedness among a number of the plant kingdom including Brassica (Li and Quiros 2001), Cucurbita (Ferriol et al. 2003), Persimmon (Guo and Luo 2006), Citrus (Uzun et al. 2009), Tree peony (Guo et al. 2009), and Sesame (Zhang et al. 2010). So far, there are no reports of measuring genetic diversity and relationships of Pongamia species by SRAP markers. In this study, we investigated SRAP markers to better assess genetic diversity and relationships among Indigenous wild species of Pongamia.

\section{MATERIALS AND METHODS}

\subsection{Plant material}

Thirty seven accessions of Pongamia pinnata representing different geographical locations from three states of India (Figure. 1) were analyzed for genetic diversity study (Table 1). Five grams of young leaf tissue was harvested from individual plants and DNA was isolated from the leaf tissue as per Tatikonda et al (2009). The quantity of the DNA was estimated using UV-spectrophotometer and quality was checked on $0.8 \%$ agarose gel.

Table 1.Details of the Pongamia pinnata samples and their place of collection used in the present study

\begin{tabular}{|c|c|c|c|c|c|c|c|}
\hline $\begin{array}{c}\text { S. } \\
\text { No. }\end{array}$ & Varieties & $\begin{array}{c}\text { Accession } \\
\text { number }\end{array}$ & $\begin{array}{c}\text { Place of } \\
\text { collection }\end{array}$ & District & Latitude & Altitude & Longitude \\
\hline 1 & RPK-5 & IC-573867 & Rajasthan & Udaipur & $24^{0} 58^{\prime}$ & 829.1 & $73^{0} 25^{\prime}$ \\
\hline 2 & RPK-1 & IC-573863 & Rajasthan & Udaipur & $24^{0} 34^{\prime}$ & $485.5^{\prime}$ & $74^{0} 16^{\prime}$ \\
\hline 3 & RPK-15 & IC-573877 & Rajasthan & Rajsamand & $25^{0} 07^{\prime}$ & 848.9 & $73^{0} 25^{\prime}$ \\
\hline 4 & RPK-37 & IC-573899 & Rajasthan & Baran & $25^{0} 10^{\prime}$ & 225.2 & $76^{0} 15^{\prime}$ \\
\hline 5 & RPK-23 & IC-573885 & Rajasthan & Bhilwara & $25^{0} 58^{\prime}$ & 393.8 & $74^{0} 42^{\prime}$ \\
\hline 6 & RPK-20 & IC-573882 & Rajasthan & Chittorgarh & $25^{0} 08^{\prime}$ & 417.3 & $74^{0} 50^{\prime}$ \\
\hline 7 & RPK-25 & IC-573887 & Rajasthan & Bhilwara & $24^{0} 53^{\prime}$ & 530.0 & $74^{0} 11^{\prime}$ \\
\hline 8 & RPK-28 & IC-573890 & Rajasthan & Dungarapur & $25^{0} 27^{\prime}$ & $303.6^{\prime}$ & $73^{0} 35^{\prime}$ \\
\hline 9 & RPK-30 & IC-573892 & Rajasthan & Pratapgarh & $23^{0} 49^{\prime}$ & $198.1^{\prime}$ & $74^{0} 29^{\prime}$ \\
\hline 10 & RPK-33 & IC-573895 & Rajasthan & Udaipur & $23^{0} 30^{\prime}$ & $231.0^{\prime} 74^{0} 21^{\prime}$ \\
\hline
\end{tabular}




\begin{tabular}{|c|c|c|c|c|c|c|c|}
\hline 11 & RPK-8 & IC-573870 & Rajasthan & Dindori & $24^{0} 05^{\prime}$ & 510.5 & $74^{0} 16^{\prime}$ \\
\hline 12 & TFRI-1/09 & IC-584151 & $\begin{array}{l}\text { Madhya } \\
\text { pradesh }\end{array}$ & Jabalpur & $21^{0} 82^{\prime}$ & 610.0 & $78^{\circ} 90^{\prime}$ \\
\hline 13 & TFRI-7/09 & IC-584157 & $\begin{array}{l}\text { Madhya } \\
\text { pradesh }\end{array}$ & Jabalpur & $22^{0} 94^{\prime} \mathrm{N}$ & 393.0 & $79^{\circ} 92^{\prime}$ \\
\hline 14 & CRIDA-HYD-58 & -- & Hyderabad & Guntur & $16^{0} 18^{\prime}$ & 134.0 & $80^{\circ} 26^{\prime}$ \\
\hline 15 & CRIDA-HYD-59 & -- & Hydrabad & Guntur & $16^{0} 18^{\prime}$ & 134.0 & $80^{\circ} 26^{\prime}$ \\
\hline 16 & CRIDA-HYD-61 & -- & Hydrabad & Guntur & $16^{0} 18^{\prime}$ & 134.0 & $80^{\circ} 26^{\prime}$ \\
\hline 17 & CRIDA-HYD-64 & -- & Hydrabad & Prakasham & $15^{\circ} 43^{\prime}$ & 391.0 & $79^{\circ} 33^{\prime}$ \\
\hline 18 & CRIDA-HYD-65 & -- & Hydrabad & Prakasham & $15^{\circ} 43^{\prime}$ & 391.0 & $79^{\circ} 33^{\prime}$ \\
\hline 19 & CRIDA-HYD-66 & -- & Hydrabad & Prakasham & $15^{\circ} 43^{\prime}$ & 391.0 & $79^{\circ} 33^{\prime}$ \\
\hline 20 & CRIDA-HYD-91 & -- & Hydrabad & Srikakulam & $18^{\circ} 17^{\prime}$ & 46.0 & $83^{\circ} 53^{\prime}$ \\
\hline 21 & CRIDA-HYD-95 & -- & Hydrabad & Visakhapatanam & $17^{0} 53^{\prime}$ & 421.0 & $82^{0} 51^{\prime}$ \\
\hline 22 & CRIDA-HYD-96 & -- & Hydrabad & Visakhapatanam & $17^{0} 53^{\prime}$ & 421.0 & $82^{0} 51^{\prime}$ \\
\hline 23 & CRIDA-HYD-98 & -- & Hydrabad & Visakhapatanam & $17^{0} 53^{\prime}$ & 421.0 & $82^{0} 51^{\prime}$ \\
\hline 24 & CRIDA-HYD-99 & -- & Hydrabad & Visakhapatanam & $17^{0} 53^{\prime}$ & 421.0 & $82^{0} 51^{\prime}$ \\
\hline 25 & $\begin{array}{c}\text { CRIDA-HYD- } \\
134\end{array}$ & -- & Hydrabad & Medak & 17.62911 & 1837.0 & 77.61911 \\
\hline 26 & $\begin{array}{l}\text { CRIDA-HYD- } \\
135\end{array}$ & -- & Hydrabad & Nizamabad & 18.658 & 1182.0 & 77.88113 \\
\hline 27 & $\begin{array}{c}\text { CRIDA-HYD- } \\
137\end{array}$ & -- & Hydrabad & Nizamabad & 18.58978 & 1274.0 & 77.95614 \\
\hline 28 & $\begin{array}{c}\text { CRIDA-HYD- } \\
150\end{array}$ & -- & Hydrabad & Karimnagar & 18.83027 & 784.0 & 78.93810 \\
\hline 29 & CRIDA-6 & IC-571514 & Hydrabad & Visakhapatnam & 17.6924 & 692.0 & 83.2102 \\
\hline 30 & CRIDA-7 & IC-571515 & Hydrabad & Visakhapatnam & 17.6924 & 692.0 & 83.2102 \\
\hline 31 & CRIDA-35 & IC-571544 & Hydrabad & Khammam & 17.2526 & 421.0 & 80.1538 \\
\hline 32 & CRIDA-129 & IC-571560 & Hydrabad & Medak & 18.0364 & 1507.0 & 78.2676 \\
\hline 33 & CRIDA-34 & IC-571543 & Hydrabad & Khammam & 17.2526 & 421.0 & 80.1538 \\
\hline 34 & CRIDA-1 & IC-571501 & Hydrabad & East Godavari & 17.4188 & 419.0 & 82.0505 \\
\hline 35 & CRIDA-116 & IC-571552 & Hydrabad & Medak & 18.0364 & 1507.0 & 78.2676 \\
\hline 36 & CRIDA-19 & IC-571528 & Hydrabad & Vizianagaram & 18.1139 & 203.0 & 83.3965 \\
\hline 37 & IGAUPP-01 & -- & $\begin{array}{c}\text { Andra } \\
\text { Pradesh }\end{array}$ & & 17.0251 & 425.0 & 80.0553 \\
\hline
\end{tabular}

\subsection{RAPD amplification}

Pongamia pinnata genome surveyed using fifty RAPD primers from the Operon series (Operon Technologies, USA) that generated reproducible and most polymorphic patterns. Composition of PCR reaction mixture used as described by Lakhanpaul et al, (2000). PCR reactions were carried out in a DNA thermal cycler (BIOER Xp Cycler). The PCR amplification conditions were followed as: initial extended step of denaturation at $94^{\circ} \mathrm{C}$ for $5 \mathrm{~min} ; 40$ cycles of denaturation $\left(94^{\circ} \mathrm{C}\right.$ for $\left.1 \mathrm{~min}\right)$, primer annealing $\left(32^{\circ} \mathrm{C}\right.$ for $\left.1 \mathrm{~min}\right)$ and primer elongation $\left(72^{\circ} \mathrm{C}\right.$ for $\left.1 \mathrm{~min}\right)$, followed by one extended primer elongation step at $72^{\circ} \mathrm{C}$ for $5 \mathrm{~min}$. The PCR amplified products were mixed with $2.5 \mu \mathrm{l}$ of $10 \mathrm{X}$ loading dye $(0.25 \%$ bromophenol blue, $0.25 \%$ xylene cyanol FF and $40 \%$ sucrose, w/v) and centrifuged briefly in a microfuge before loading (Sambrook, Fritsch and Maniatis, 1989). The amplification products were size separated by electrophoresis on $1.8 \%$ agarose gels prepared in 1 X TAE at 100 volts. Gels were stained with ethidium bromide (1mg/ml) and photograph from Syngene gel documentation system. 


\subsection{SRAP amplification}

SRAP analysis was conducted according to previously established protocols (Li and Quiros 2001). In this assay, 70 different primer combinations were employed using six forward primers and six reverse primers combined randomly (Table 2). Firstly, SRAP primer combinations were screened. After screening under the optimized condition, primer combinations, generated strong and clear amplified bands, were selected for further investigations. Polymerase chain reaction was performed in $20 \mu \mathrm{L}$ reaction mixture containing $1 \times$ buffer, $2.0 \mathrm{mM} \mathrm{MgCl} 2,0.2 \mathrm{mM}$ dNTPs, $1 \mathrm{U}$ Taq DNA polymerase, 0.5 $\mu \mathrm{M}$ primers, $50 \mathrm{ng}$ DNA templates. Amplifications were carried out in a DNA thermal cycler (BIOER Xp Cycler) with an initial step at $94^{\circ} \mathrm{C}$ for $5 \mathrm{~min}$, and five cycles of $1 \mathrm{~min}$ at $94^{\circ} \mathrm{C}, 1 \mathrm{~min}$ at $35^{\circ} \mathrm{C}$, and $1.5 \mathrm{~min}$ at $72^{\circ} \mathrm{C}$. The following $35 \mathrm{cycles}$ consisted of $94^{\circ} \mathrm{C}$ for $1 \mathrm{~min}, 50^{\circ} \mathrm{C}$ for $1 \mathrm{~min}$, and $72^{\circ} \mathrm{C}$ for $1 \mathrm{~min}$, with a final extension at $72^{\circ} \mathrm{C}$ for $10 \mathrm{~min}$. The PCR reactions were repeated twice for each primer pair to ensure reproducibility. Amplified products were separated on $1.5 \%$ agarose gels in 1× TAE buffer using DNA marker as molecular weight marker and visualized with ethidium bromide staining.

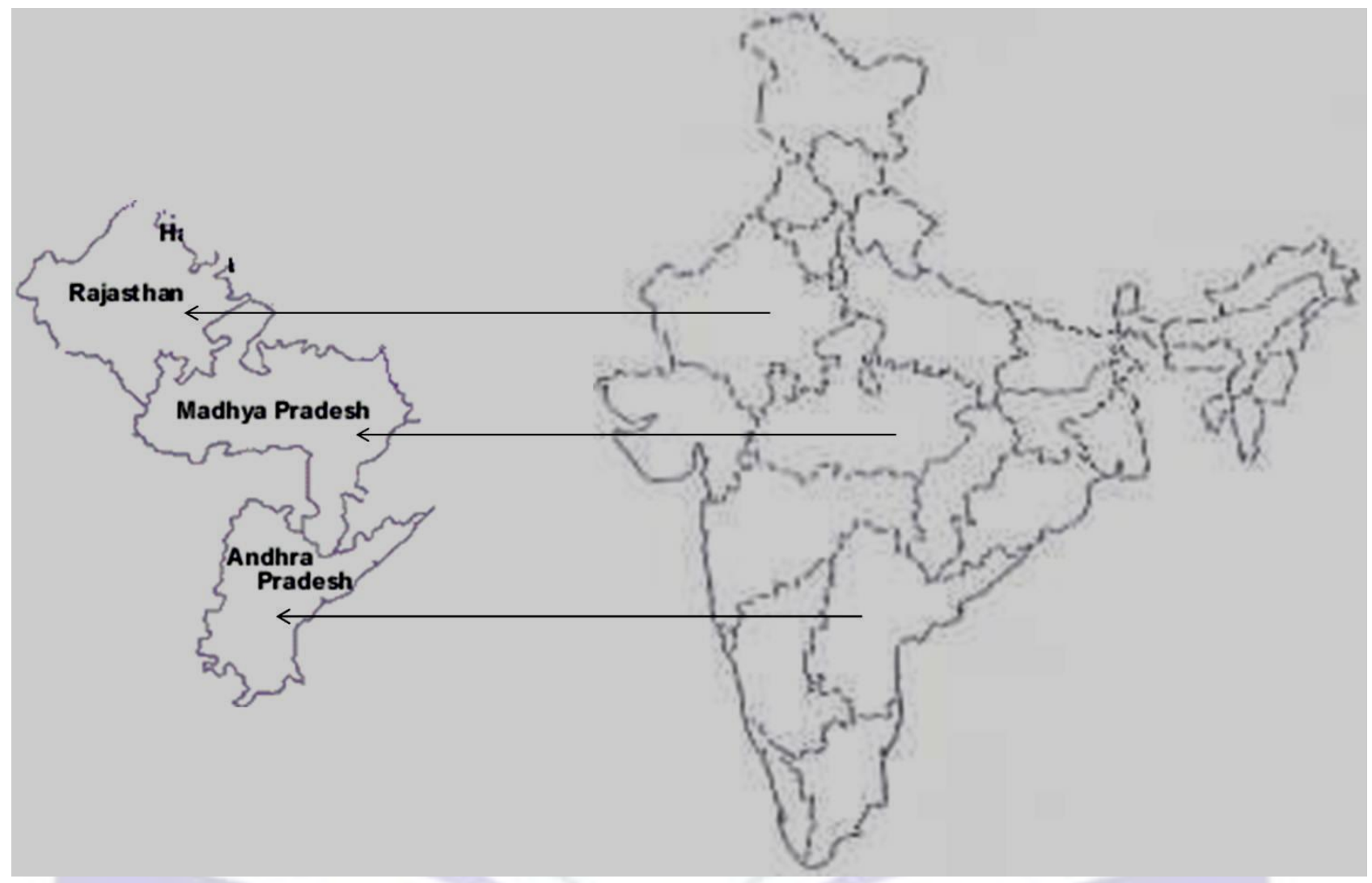

Fig 1: Samples collected from the above three states of India for the present study.

\subsection{Data analysis}

The amplified bands for all the individuals were scored as either 1 (present) or 0 (absent), and only clear repetitive, wellseparated, and intense bands that were observed in all the two independent amplifications were selected for scoring in a binary matrix. Pair-wise comparisons between varieties were made using the Nei and Li similarity coefficients with SIMQUAL module of the software package NTSYS-pc (Rohlf 2005) from the binary matrix. The similarity matrix was used to construct a dendrogram for all 37 genotypes based on the unweighted pair group method with arithmetic averaging (UPGMA) using the SHAN module of NTSYS-pc. Polymorphism information content (PIC) values were calculated according to Smith et al. (1997). Principal co-ordinate analysis (PCoA) was performed based on the similarity coefficients using DCENTER module to transform the symmetric similarity matrix to scalar product form and then EIGEN module was used to extract eigenvectors resulting into a PCOORDA. First three vectors were used to construct a three-dimensional coordinate plot.

\section{RESULTS}

\subsection{Genetic variation of RAPD markers}

Initial screening was done with 150 primers. Only eighteen primers were found to be reproducible which were used to assess genetic diversity among 37 accessions of Pongamia pinnata. While rest of the primers resulted were either no amplification or smeared profiles. These eighteen primers yielded 157 bands/ fragments. The number of amplified 
fragments ranged from 3 (OPC 4) to 16 (OPB 18) with an average of 8.72 bands per primer (Table-2). The size of the amplified fragments ranged from $150-6000 \mathrm{bp}$. Out of 157 bands scored $150(96.86 \%)$ were polymorphic and rest were monomorphic. The range of polymorphic was $81.8 \%$ to $100 \%$. The PIC values for the 18 random primers were ranged from 0.37 (OPC 4) to 0.90 (OPB 18) with a mean of 0.77 . The PIC results for each marker confirmed their utility to show difference between the samples analyzed in the present study.

The pair wise comparison of the RAPD profiles based on both shared and unique amplification product was made to generate a similarity matrix. Similarity indices estimated on the basis of eighteen primers ranged from 0.13 to 0.77 with an average value of 0.40 similarities between accessions. The lowest genetic similarity $(0.13)$ was found between CRIDA 134 from Medhak district of Hydrabad and CRIDA 19 Vizianagaram district of Hydrabad. The highest genetic similarity was found between IC573887 and IC573877. Both the accessions were collected from Bhilwara and Rajsamand district of Rajasthan. The high diversity reveled by RAPD is an agreement with the conclusion that out breeding plant species exhibit considerable variability. This was further supported by molecular marker studied. The maintenance of a high genetic variation within accessions was favored by genetic system of the species like gene flow, out breeding, mutation, high genetic load etc.

Table 2. Profile of RAPD bands generated by eighteen primers used to analyze genetic diversity of Pongemia pinnata genotypes.

\begin{tabular}{|c|c|c|c|c|c|c|c|}
\hline $\begin{array}{c}\text { SI } \\
\text { No }\end{array}$ & Primer & 5' to 3' Sequence & $\begin{array}{c}\text { Product } \\
\text { Size }\end{array}$ & $\begin{array}{c}\text { No. of } \\
\text { total } \\
\text { bands }\end{array}$ & $\begin{array}{c}\text { No. of } \\
\text { Polymorp } \\
\text { him } \\
\text { bands }\end{array}$ & $\begin{array}{c}\text { \% of } \\
\text { Polymorp } \\
\text { him }\end{array}$ & PIC \\
\hline 1 & OPC4 & CCGCATCTAC & $1400-1000$ & 3 & 3 & 100 & 0.371 \\
\hline 2 & OPC5 & GATGACCGCC & $2200-600$ & 5 & 5 & 100 & 0.729 \\
\hline 3 & OPC8 & TGGACCGGTG & $2500-850$ & 5 & 5 & 100 & 0.705 \\
\hline 4 & OPC11 & AAAGCTGCGG & $2200-150$ & 12 & 10 & 83.3 & 0.826 \\
\hline 5 & OPC12 & TGTCATCCCC & $2000-400$ & 10 & 10 & 100 & 0.816 \\
\hline 6 & OPC15 & GACGGATCAG & $2500-550$ & 10 & 10 & 100 & 0.845 \\
\hline 7 & OPC14 & TGCGTGCTTG & $1500-600$ & 6 & 6 & 100 & 0.627 \\
\hline 8 & OPB18 & CCACAGCAGT & $6000-200$ & 16 & 14 & 87.5 & 0.897 \\
\hline 9 & OPN17 & CATTGGGAG & $1500-500$ & 6 & 6 & 100 & 0.663 \\
\hline 10 & OPG7 & GAACCTGCGG & $1800-800$ & 7 & 7 & 100 & 0.824 \\
\hline 11 & OPO3 & CTGTTGCTAC & $1200-200$ & 11 & 10 & 90.9 & 0.870 \\
\hline 12 & OPO10 & TCAGAGCGCC & $1500-300$ & 11 & 11 & 100 & 0.824 \\
\hline 13 & OPO16 & TCGGCGGTTC & $1200-450$ & 8 & 8 & 100 & 0.827 \\
\hline 14 & OPO19 & GGTGCACGTT & $1500-400$ & 8 & 8 & 100 & 0.730 \\
\hline 15 & OPM1 & GTTGGTGGCT & $1200-300$ & 10 & 10 & 100 & 0.862 \\
\hline 16 & OPM5 & GGGAACGTGT & $2500-300$ & 11 & 11 & 100 & 0.845 \\
\hline 17 & OPM12 & GGGACGTTGG & $1800-300$ & 11 & 9 & 81.8 & 0.874 \\
\hline 18 & OPP18 & GGCTTGGCCT & $1000-300$ & 7 & 7 & 100 & 0.751 \\
\hline & Total & & & $\mathbf{1 5 7}$ & $\mathbf{1 5 0}$ & $\mathbf{9 6 . 8 6}$ & $\mathbf{0 . 7 7 1}$ \\
\hline
\end{tabular}

\subsection{Genetic Variation of SRAP markers}

A total of 100 SRAP combinations were tried with three samples and twenty three combinations were found informative due to their ability to produce clearly and repeatedly and unambiguous bands among the varieties (Table-3). These three varieties were chosen because of their geographic representation i.e. one each from Madhya Pradesh (IC-573867), Rajasthan (IC-584157) and Andhra Pradesh (IC-571514). A total of 145 bands were amplified ranging in size from 100 to $1600 \mathrm{bp}$. The total no bands scored per primer combination ranged from 4 (ME1 + EM1) to 10 (ME12 + EM9) with an average of 6 bands per primer combination. Out of these bands 122 bands were polymorphic at a ranged from $40-100 \%$ with an average of $84.07 \%$ among the 37 varieties. Unique bands with their respective size and accessions number is given in table no.4. The PIC values for the 23 primer combinations were ranged from 0.61 (ME13 + EM5) to 0.82 (ME1+EM1) with a mean of 0.68 . 
ISSN 2348-6201

Table 3. Profile of SRAP bands generated by eighteen primers used to analyze genetic diversity of Pongemia pinnata genotypes.

\begin{tabular}{|c|c|c|c|c|c|c|c|}
\hline $\begin{array}{l}\text { S. } \\
\text { No. }\end{array}$ & Primer & 5 ' to $3^{\prime}$ Sequence & $\begin{array}{l}\text { Product } \\
\text { Size }\end{array}$ & $\begin{array}{l}\text { No. of } \\
\text { total } \\
\text { bands }\end{array}$ & $\begin{array}{c}\text { No.of } \\
\text { Polymo } \\
\text { rphic } \\
\text { bands }\end{array}$ & $\begin{array}{l}\% \text { of } \\
\text { Polym } \\
\text { orphim }\end{array}$ & PIC \\
\hline 1. & $\mathrm{ME} 1+\mathrm{EM} 1$ & $\begin{array}{l}\text { F-TGA GTC CAA ACC GGA TA } \\
\text { R- GAC TGC GTA CGA ATT AAT }\end{array}$ & $750-200$ & 4 & 4 & 100 & 0.631 \\
\hline 2. & ME1+EM3 & $\begin{array}{l}\text { F- TGA GTC CAA ACC GGA TA } \\
\text { R- GAC TGC GTA CGA ATT GAC }\end{array}$ & $900-150$ & 8 & 8 & 100 & 0.822 \\
\hline 3. & $\mathrm{ME} 1+\mathrm{EM} 4$ & $\begin{array}{l}\text { F- GAC TGC GTA CGA ATT TGA } \\
\text { R- GAC TGC GTA CGA ATT TGAC }\end{array}$ & $1200-200$ & 7 & 7 & 100 & 0.676 \\
\hline 4. & ME1+EM15 & $\begin{array}{l}\text { F- TGA GTC CAA ACC GGA TA } \\
\text { R- GAC TGC GTA CGA ATT GAT }\end{array}$ & $800-200$ & 6 & 6 & 100 & 0.073 \\
\hline 5. & ME1+EM16 & $\begin{array}{l}\text { F- TGA GTC CAA ACC GGA TA } \\
\text { R- GAC TGC GTA CGA ATT GTC }\end{array}$ & $1600-200$ & 6 & 6 & 100 & 0.627 \\
\hline 6. & ME1+ EM17 & $\begin{array}{l}\text { F- TGA GTC CAA ACC GGA TA } \\
\text { R- GAC TGC GTA CGA ATT GAG }\end{array}$ & $600-150$ & 5 & 2 & 40 & 0.735 \\
\hline 7. & $\mathrm{ME} 1+\mathrm{EM} 6$ & $\begin{array}{l}\text { F- TGA GTC CAA ACC GGA TA } \\
\text { R- GAC TGC GTA CGA ATT GCA }\end{array}$ & $1100-280$ & 7 & 7 & 100 & 0.735 \\
\hline 8. & $\mathrm{ME} 11+\mathrm{EM} 8$ & $\begin{array}{l}\text { F- TGA GTC CAA ACC GGA AC } \\
\text { R- GAC TGC GTA CGA ATT CAC }\end{array}$ & $1200-100$ & 6 & 5 & 83.3 & 0.678 \\
\hline 9. & $\mathrm{ME} 12+\mathrm{EM} 3$ & $\begin{array}{l}\text { F- TGA GTC CAA ACC GGA GA } \\
\text { R- GAC TGC GTA CGA ATT GAC }\end{array}$ & $1200-250$ & 7 & 3 & 42.8 & 0.620 \\
\hline 10. & ME12+ EM9 & $\begin{array}{l}\text { F- TGA GTC CAA ACC GGA GA } \\
\text { R- GAC TGC GTA CGA ATT CAG }\end{array}$ & $850-150$ & 8 & 7 & 87.5 & 0.780 \\
\hline 11. & ME12+ EM9 & $\begin{array}{l}\text { F- TGA GTC CAA ACC GGA GA } \\
\text { R- GAC TGC GTA CGA ATT CAG }\end{array}$ & $1030-50$ & 10 & 9 & 90 & 0.809 \\
\hline 12. & ME14+EM10 & $\begin{array}{l}\text { F- TGA GTC CAA A CC GGT GC } \\
\text { R- GAC TGC GTA CGA ATT CAT }\end{array}$ & $550-250$ & 6 & 4 & 66.6 & 0.711 \\
\hline 13. & ME14+ EM7 & $\begin{array}{l}\text { F- TGA GTC CAA A CC GGT GC } \\
\text { R- GAC TGC GTA CGA ATT CAA }\end{array}$ & $700-250$ & 5 & 5 & 100 & 0.697 \\
\hline 14. & ME14+ EM3 & $\begin{array}{l}\text { F- TGA GTC CAA A CC GGT GC } \\
\text { R- GAC TGC GTA CGA ATT GAC }\end{array}$ & $500-150$ & 5 & 5 & 100 & 0.694 \\
\hline 15. & ME14+ EM5 & $\begin{array}{l}\text { F- TGA GTC CAA A CC GGT GC } \\
\text { R- GAC TGC GTA CGA ATT AAC }\end{array}$ & $450-200$ & 5 & 5 & 100 & 0.706 \\
\hline 16. & ME13+ EM1 & $\begin{array}{l}\text { F- GAC TGC GTA CGA ATT AAC } \\
\text { R- GAC TGC GTA CGA ATT AAT }\end{array}$ & $900-150$ & 8 & 7 & 87.5 & 0.755 \\
\hline 17. & ME13+ EM3 & $\begin{array}{l}\text { F- GAC TGC GTA CGA ATT AAC } \\
\text { R- GAC TGC GTA CGA ATT GAC }\end{array}$ & $1200-200$ & 6 & 5 & 83.3 & 0.731 \\
\hline 18. & ME13+ EM2 & $\begin{array}{l}\text { F- GAC TGC GTA CGA ATT AAC } \\
\text { R- GAC TGC GTA CGA ATT TGC }\end{array}$ & $1000-150$ & 6 & 4 & 66.6 & 0.731 \\
\hline 19. & ME14+EM13 & F- TGA GTC CAA A CC GGT GC & $1300-200$ & 7 & 5 & 71.4 & 0.755 \\
\hline
\end{tabular}


ISSN 2348-6201

\begin{tabular}{|c|c|c|c|c|c|c|c|}
\hline & & R- GAC TGC GTA CGA ATT CTG & & & & & \\
\hline 20. & ME13+ EM7 & $\begin{array}{l}\text { F- GAC TGC GTA CGA ATT AAC } \\
\text { R- GAC TGC GTA CGA ATT CAA }\end{array}$ & $500-200$ & 5 & 4 & 80 & 0.698 \\
\hline 21. & ME13+ EM5 & $\begin{array}{l}\text { F- GAC TGC GTA CGA ATT AAC } \\
\text { R- GAC TGC GTA CGA ATT AAC }\end{array}$ & $500-150$ & 5 & 4 & 80 & 0.609 \\
\hline 22. & ME13+ EM4 & $\begin{array}{l}\text { F- GAC TGC GTA CGA ATT AAC } \\
\text { R- GAC TGC GTA CGA ATT TGA }\end{array}$ & $700-250$ & 7 & 5 & 71.4 & 0.638 \\
\hline 23. & ME13+ EM9 & $\begin{array}{l}\text { F- GAC TGC GTA CGA ATT AAC } \\
\text { R- GAC TGC GTA CGA ATT CAG }\end{array}$ & $1000-200$ & 6 & 5 & 83.3 & 0.742 \\
\hline & & Total & & 145 & 122 & 84.07 & 0.681 \\
\hline
\end{tabular}

The pair wise comparison of the SRAP profiles based on both shared and unique amplification product was made to generate a similarity matrix. Similarity indices estimated on the basis of twenty three primers ranged from 0.20 to 0.93 with an average value of 0.57 similarities between accessions. The lowest genetic similarity $(0.20)$ was found between CRIDA 134 from Medhak district of Hydrabad and CRIDA 59 Guntur district of Hydrabad. The highest genetic similarity was found between IC573885 and IC573899. Both the accessions were collected from Bhilwara and Rajsamand district of Baran.

\subsection{Combined SRAP and RAPD analysis}

The similarity matrix was used to construct a dendrogram for all 37 genotypes based on the unweighted pair group method with arithmetic averaging (UPGMA) using both RAPD and SRAP data. The UPGMA clustered the 37 genotypes into four major clusters. All the genotypes were showed similarity according to their origin states.

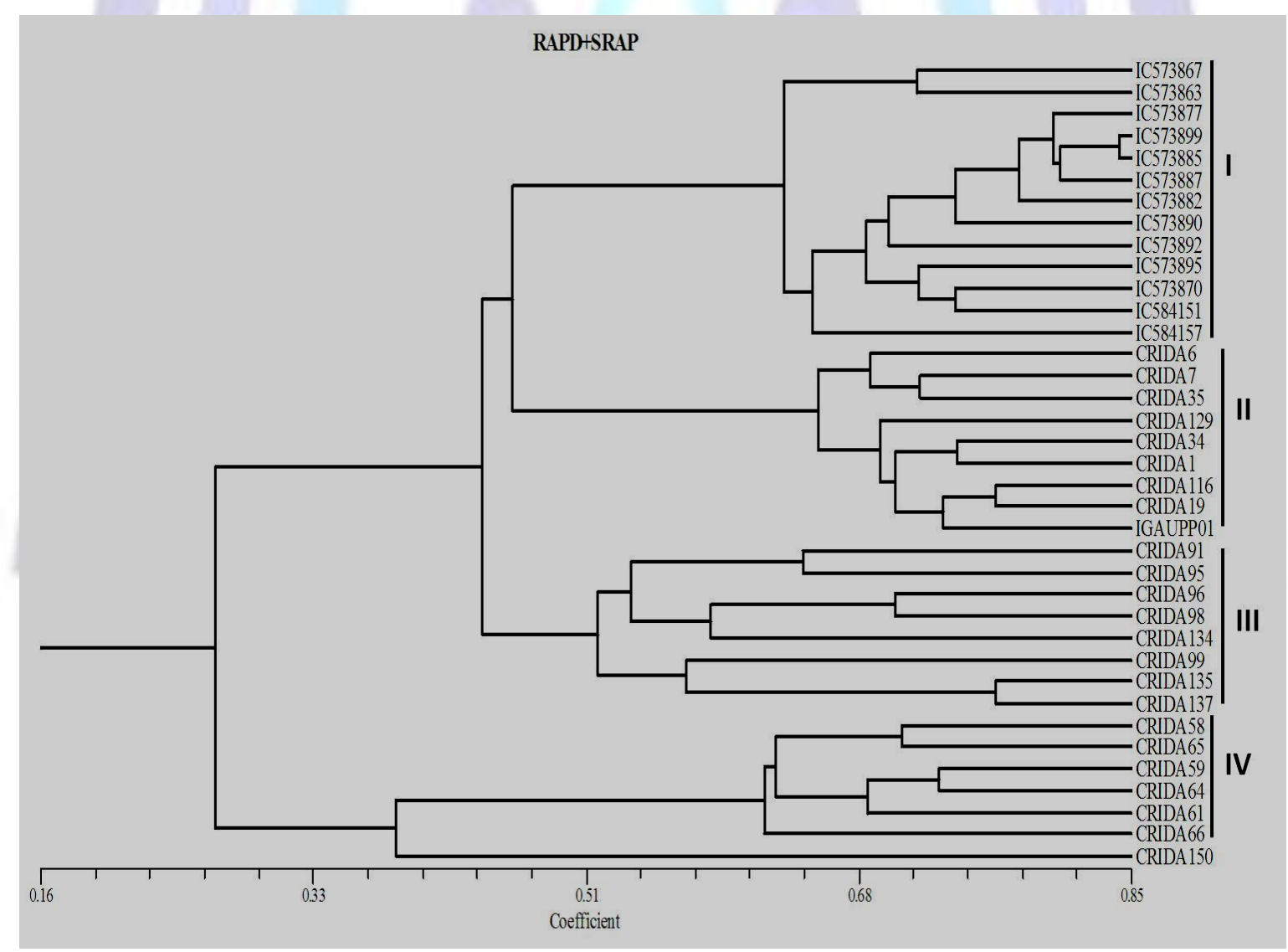

Fig 2: Unweighted pair group method of arithmetic (UPGMA) averages dendrogram based on Jaccard's similarity coefficients constructed using RAPD and SRAP data.

Cluster I consists of thirteen genotypes out of them eleven from Rajasthan and two from Madhya Pradesh. Accession IC584157 was the most diverse (64\%) with in this cluster. The maximum similarity was $84 \%$ between IC573899 and IC573885. Nine genotypes from Andhra Pradesh were grouped into Cluster II. Again it is dividing into two sub-clusters. 
One sub-cluster consist of CRIDA6, CRIDA7 and CRIDA35 and another one consist of CRIDA129, CRIDA34, CRIDA1, CRIDA116, CRIDA19, IGAUPP01 among them CRIDA6 and CRIDA34 are the most diverse genotypes. The most diverse cluster is cluster III, which is consist eight genotypes. Maximum similarity was showed in CRIDA135 and CRIDA137 (76\%). CRIDA134 and CRIDA99 are the most diverse genotypes for this cluster. Cluster IV consist of six genotypes which is further divided in to two sub-clusters. In one sub-cluster CRIDA58 and CRIDA65 are showing $70 \%$ similarity. Another sub-cluster showing 72\% similarities between CRIDA61 and CRIDA64, and 64\% similarities between CRIDA61 and CRIDA59. CRIDA66 is the most diverse for the cluster IV. CRIDA150 branched out separately in out-group, suggesting that it is remarkably diverse than rest of the genotypes. Much cannot be said about that relatedness or diversity of these genotypes on the basis of their evolutionary origin because they are a random collection from Andhra Pradesh.

To obtain an alternative view of the relationship between the varieties Principle Component Analysis was done with combined data (Figure 3). The results of PCA analysis were comparable to the cluster analysis (Figure 2). The twodimensional ordination confirms the cluster analysis results showing that the genotype CRIDA150 was separated. Besides formation of dendrogram other genenetic variation studies were also performed on ISSR and RAPD combined data which are represented in different tables (Tables $4-6)$. Projection of accessions on a two-dimensional plane defined by the first two axes revealed four groups (Figure. 3), same to the UPGMA cluster analysis. The varieties of group 1, group 2, group 3 and group 4 in PCoA plot are exactly same as to cluster I, cluster II, cluster III and cluster IV in the dendrogram. The varieties' distributions on the PCoA plot as in the dendrogram suggest distinct differentiation among the different groups.

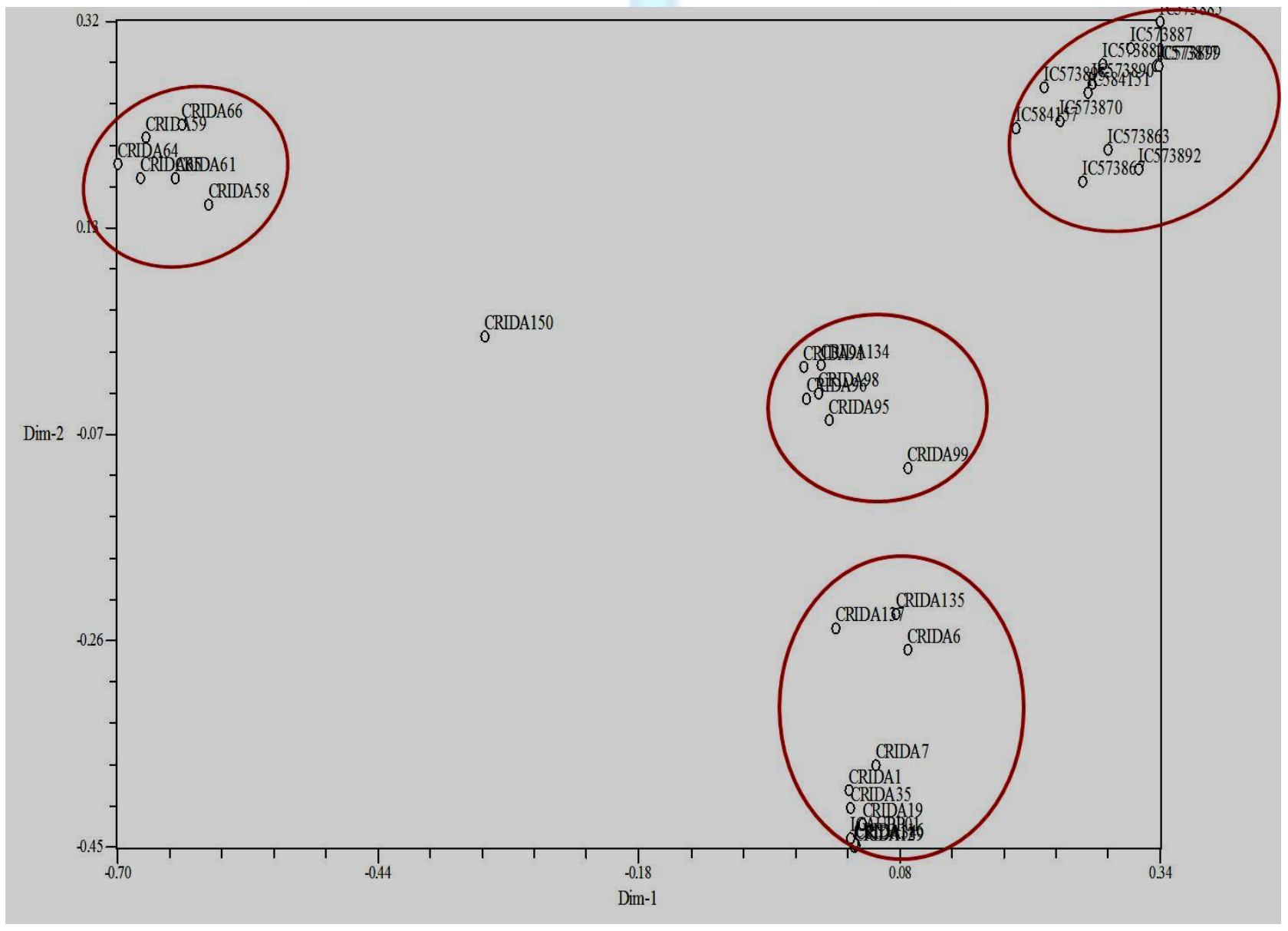

\section{Fig 3: Two dimensional PCA (Principle Component Analysis) scaling of 37 accessions of Pongamia using RAPD and SRAP markers.}

\section{DISCUSSION}

Researchers have identified $P$. pinnata as a source of biodiesel, and much of the work being done on this crop is in infancy stages. But many other crops are known which have the potential for biodiesel production, Jatropha is one such biodiesel yielding plant. Several studies on molecular markers on these biodiesel plants are going on. Randomly amplified polyorphic DNA (RAPD) markers have been successfully employed for determination of genetic diversity in several plants, such as date palm (Corniquel and Mercier 1994), papaya (Stiles et al., 1993), poplars (Bradshaw et al.1994), amaranths (Ranade et al.1997), cucumber (Horejsi and staub, 1999), potato (Demeke et al.1996) and pepper (Prince et al. 1995). In this work we compared the applicability of SRAP and RAPDs as genetic markers to characterize the thirty seven $P$. pinnata genotypes. However, no sufficient reports on genetic diversity using molecular markers were available in the 
genus Pongamia. In the present study, an attempt has been made to examine the level of genetic variation within $P$. pinnata from different agro climatic condition.

The frequencies of the polymorphic fragments for both the RAPD and SRAP primer combination across 37 accessions, 0.37 to 0.89 with an average 0.77 and 0.20 to 0.93 with an average of 0.57 . Similar results were also reported in Pongamia (Thudi et al. 2010), Jatropha (Taikonda et al. 2009) and Sinapis alba (Yong-Bi et al. 2006). The level of polymorphism detected by RAPD in the present study (96.68) is comparable to the other RAPD diversity studies (99\%, 82.4\%) (Raina et al., 2000, Ram and Thiruvengadam 2007) and by SRAP (84.07) is comparable to the other diversity studies (96.5\%) (Thudi et al.2010). The pair wise genetic similarity among 37 Pongamia pinnata accessions ranged from 0.19 to 0.84 with an average of 0.48 .

Table 4: Number of Unique bands and their respective size produced form SRAP markers.

\begin{tabular}{|c|c|c|c|c|}
\hline SI no & Primers & Unique Band & Size in bp. & Accession Number \\
\hline 1 & Me1+EM16 & 1 & 200 & CRIDA-6 \\
\hline 2 & Me1+EM15 & 1 & 750 & CRIDA-HYD-66 \\
\hline 3 & ME11+EM6 & 1 & 400 & CRIDA-HYD-150 \\
\hline 4 & ME12+EM3 & 1 & 900 & CRIDA-HYD-65 \\
\hline 5 & ME12+EM3 & 1 & 1200 & IC-573882 \\
\hline 6 & ME13+EM3 & 1 & 1200 & CRIDA-HYD-65 \\
\hline 7 & ME14+EM13 & 1 & 1300 & CRIDA-HYD-150 \\
\hline 8 & ME13+EM4 & 1 & 600 & IC-584151 \\
\hline
\end{tabular}

Table 5: Jaccard's similarity statistics for RAPD, SRAP and RAPD+SRAP in Pongamia pinnata.

\begin{tabular}{|c|c|c|c|}
\hline Statistics & RAPD & SRAP & RAPD+ SRAP \\
\hline Maximum similarity value & 0.77 & 0.93 & 0.84 \\
\hline Minimum similarity value & 0.13 & 0.20 & 0.19 \\
\hline Average & 0.40 & 0.57 & 0.48 \\
\hline
\end{tabular}

S. Ganesh Ram and V. Thiruvengadam (2007) investigated the genetic diversity of 12 Jatropha species based on RAPD markers. From 26 random primers used, 18 primers gave reproducible amplification banding patterns of 112 polymorphic bands out of 134 bands scored accounting for $80.2 \%$ polymorphism across the genotypes. Jaccard's coefficient of similarity varied from 0.16 to 0.85 , indicative of high level of genetic variation among the genotypes studied. The result provides valid guidelines for collection, conservation and characterization of Jatropha genetic resource.

Nagella et al. (2007) with the use of RAPD marker investigated the genetic diversity of selected 18 Indian niger germplasm accesssions from different origin and pedigree background. The study was the first attempt to estimate genetic variability among Indian niger cultivated using RAPD markers. RAPD analysis using 80 arbitary 10-mer primers yielded a total of 124 bands, $41.20 \%$ of them were polymorphic. The study revealed the geographical distribution of the 18 niger cultivars influence the RAPD variation between closely related cultivars.

Raina et al., (2000) used twenty-one random primers to assess genetic variation and phylogenetic relationship among cultivated peanut and wild species of the genus arachis. In contrast with the previous generalizations that peanut accessions lack genetic variation, random primers revealed $42.7 \%$ polymorphism. Although the polymorphic index content varied from 0.35 to 4.65 for RAPD markers. It was possible to identify accessions, particularly those of divergent origins, by RAPD fingerprints. Subhash et al (2003) used RAPD markers to study the genetic relationships among 10 species belonging to 2 sections of the genus Dalbergia. A total of 224 RAPD bands were observed with an average of 22.4 bands per primer, of which $99 \%$ were polymorphic.

RAPD and SRAP fingerprinting has been successful in detecting variation in pongamia genotypes. Variation between the genotype was observed with the help of 18 selected RAPD primers and 23 selected SRAP primers. The high percentage of polymorphism amongst the genotypes tested suggests the existence of high level of diversity in Pongamia samples collected from different districts of Rajasthan, Madhya Pradesh and Andhra Pradesh. These primers should be used for future studies involving characterization of larger germplasm collection in Pongamia pinnata. Further, the DNA fingerprints developed can be used for cultivator or genotype identification of Pongamia pinnata.

In conclusion, the results of the present study suggest that the SRAP markers are being highly reproducible and efficient as a powerful tool to assess genetic relationships among domesticated and wild genotypes. 


\section{ACKNOWLEDGMENTS}

Grateful thanks to NOVOBD, Ministry of Agriculture for the supply of seed samples and financial support. We also thank to the Director, NBPGR, New Delhi for providing facilities.

\section{REFERENCES}

[1] Belaj, A., Trujilo, I., Rosa, R., Rallo, L., Gimenez, M. J. 2001. Polymorphism and discrimination capacity of randomly amplified polymorphic markers in an olive germplasm bank. J Am Soc Hort Sci 126:64-71

[2] Botstein, D., White, R. L., Skolnick, M., Davis, R. W. 1980. Construction of a genetic linkage map in man using restriction fragment length polymorphism. Am J Hum Genet 32: 314-331

[3] Budak, H., Shearman, R. C., Parmaksiz, I., Dweikat, I. 2004. Comparative analysis of seeded and vegetative biotype buffalograsses based on phylogenetic relationship using ISSRs, SSRs, RAPDs, and SRAPs. Theor Appl Genet 109(2):280-288

[4] Casiva, P. V., Saidman, B. O., Vilardi, V. C., Cialdella, A. M. 2002. Am J Bot, 89: 843.

[5] Deshwall, R. P. S., Singh, R., Malik, K., Randhawa, G. J. 2005. Assessment of genetic diversity and genetic relationships among 29 populations of Azadirachta indica A. Juss. using RAPD markers. Genet Resour Crop Evol 52:285-292

[6] Ferriol, M., Pico, B., Nuez, F. 2003. Genetic diversity of a germplasm collection of Cucurbita pepo using SRAP and AFLP markers. Theor Appl Genet 107(2):271-282

[7] Fu Yong-Bi, Gugel, R. K., Katepa-Mupondwa, F. 2006. Plant Gen Res, 4: 87.

[8] Guo, D. L., Hou, X. G., Zhang, J. 2009. Sequence-related amplified polymorphism analysis of tree peony (Paeonia suffruticosa Andrews.) cultivars with different flower colours. J Horti Sci Biotech 84(2):131-136

[9] Guo, D. L., Luo, Z. R. 2006. Genetic relationships of some PCNA persimmons (Diospyros kaki Thunb.) from China and Japan revealed by SRAP analysis. Genet Resour Crop Ev 53(8):1597-1603

[10] Hudson, D. H., Richter, D. C., Rausch, C., Dezulian, T., Franz, M., Rupp, R. 2007. BMC Bioinformatics, 8: 460.

[11] Kapteyn, J., Simon, J. E. 2002. The use of RAPDs for assessment of identity, diversity, and quality of Echinacea. In: Janick J, Whipkey A (eds) Trends in new crops and new uses. ASHS Press, Alexandria, VA, pp 509-513

[12] Lakhanpaul, S., Chadha, S., Bhat, K. V. 2000. Random Amplified Polymorphic DNA (RAPD) analysis in Indian mung bean (Vigna radiata (L.) Wilczek) cultivars. Genetica 109: 227-234.

[13] Li, G., Quiros, C. F. 2001. Sequence-related amplified polymorphism (SRAP), a new marker system based on a simple PCR reaction: its application to mapping and gene tagging in Brassica. Theor Appl Genet 103(2-3):455-461

[14] Milbourne, D., Meyer, R., Bradshaw, J., Baird, E., Bonar, N., Provan, J., Powell, W., Waugh, R. 1997. Mol Breed, 3: 127.

[15] Nei, M. 1972. American Naturalist, 106: 283. 25 Swofford DL, Phylogenetic analysis using Parsimony (*and Other Methods) Version 4, Sinauer Associates, Sunderland, Massachusetts, (2003).

[16] Parani, M., Lakshmi, M., Kumar, S. P., Parida, A. 2000. Curr Sci, 78: 1235.

[17] Powell, W., Morgante, M., Andre, C., Hanafey, M., Vogel, J., Tingey, S., Rafalski, A. 1996. Mol Breed, 2: 225.

[18] Prevost, A., Wilkinson, M. J. 1999. Theor Appl Genet, 98: 107.

[19] Roldan-Ruiz, J., Dendauw, E., VanBockstaele, A., Depicker, M., Loose, De. 2000. Mol Breed, 6: 125.

[20] Sambrook, J., Fritsch, E. F., Maniatis, T. 1989. Molecular cloning: a laboratory manual. Cold Spring Harbor Laboratory, Cold Spring Harbor, New York, USA

[21] Scott, P.T., Pregelj, L., Chen, N., Gresshoff, P. M. 2008. BioEnergy Research 1: 2

[22] Tatikonda, L., Wani, S. P., Kannan, S., Beerelli, N., Hoisington, D. A., Devi, P. Varshney, R. K. 2009. AFLP-based molecular characterization of an elite germplasm collection of Jatropha curcas L., a biofuel plant Plant Sci, 176: 505-513

[23] Tautz, D. 1989. Hypervariability of simple sequences as a general source of polymorphic DNA markers. Nucleic Acids Res 17:6463-6471

[24] Thudi, M., Wani, S. P., Tatikonda, L., Hoisington, D. A., Varshney, R K. 2010. Analysis of Genetic Diversity in Pongamia [Pongamia pinnata (L) Pierrre] using AFLP Markers J. Plant Biochemistry \& Biotechnology Vol. 19(2), 209-216,

[25] Uzun, A., Yesilo, T., Aka-Kacar, Y., Tuzcu O Gulsen, O. 2009. Genetic diversity and relationships within Citrus and related genera based on sequence related amplified polymorphism markers (SRAPs).Sci Horti 121(3):306-312 


\section{ISSN 2348-6201}

[26] Varshney, R. K., Chabane, K., Hendre, P. S. Aggarwal, R. K. 2007. Plant Sci, 73: 638.

[27] Vos, P., Hogers, R., Bleeker, M., Reijans, M., Lee, T., Hornes, M., Friters, A., Pot, J., Paleman, J., Kuiper, M. Zabeau, M. 1995. Nucleic Acids Res, 23: 4407.

[28] Welsh, J., McClelland, M. 1990. Fingerprinting genomes using PCR with arbitrary primers. Nucleic Acids Res 18: 7213-7218

[29] Williams, J. G. K., Kubelik, K. J., Livak, K. J., Rafalski, J. A., Tingey, S. V. 1990. DNA polymorphisms amplified by arbitrary primers are useful genetic markers. Nucleic Acids Res 18:6531-6535

[30] Wu, Y. G., Guo, Q. S., He, J. C., Lin, Y. F., Luo, L. J., Liu, G. D. 2010. Genetic diversity analysis among and within populations of Pogostemon cablin from China with ISSR and SRAP markers. Biochem Syst Ecol 38(1):63-72

[31] Zabeau. M., Vos, P. 1993. Selective restriction fragment amplification: a general method for DNA fingerprinting. European Patent Application number 92402629.7. Publication number 534858A1

[32] Zhang, Y., Zhang, X., Hua, W., Wang, L., Che, Z. 2010. Analysis of genetic diversity among indigenous landraces from sesame (Sesamum indicum L.) core collection in China as revealed by SRAP and SSR markers. Genes Genom 32(3):207-215

\section{Author' biography with Photo}

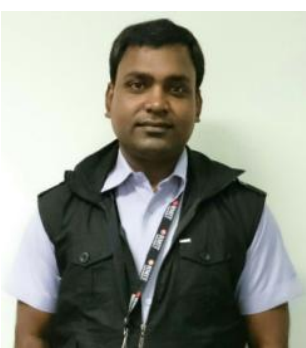

Dr. Pravas Ranjan Kole is post graduated in Biotechnology and completed his PhD in Biotechnology from Bundelkhand University of UttarPradesh, India. His current interests are on the topics of Molecular biology, Molecular marker, Biotic and Abiotic Stress response and Gene Expression study. 